$\frac{\text { DE }}{G}{ }^{\text {DE GRUYter }}$ THEN

EJAE 2017, 14(2): 1-18

ISSN 2406-2588

UDK: 340.137:347.44(497.11:4-672EU) $366.542 / .543(497.11)$

004.738.5:339

DOI: 10.5937/ejae14-12921

Original paper/Originalni naučni rad

\title{
CONSUMER PROTECTION IN INTERNET SALES- DEGREE OF HARMONIZATION WITH THE EUROPEAN UNION LAW
}

\author{
Dragana Ranđelović*, Samir Ljajić \\ University of Novi Pazar, \\ Novi Pazar, Serbia
}

\begin{abstract}
:
In this paper the authors will strive to answer some general questions regarding the concept, significance and goals of the harmonization of contract law. Given the actuality and mass state of Internet sales, questions and issues of consumer protection will be set within the boundaries of this narrow field of contract law. In the central part of the paper, the authors will present the most important regulations governing this area both in the European Union and Serbia, as well as the degree of their harmonization. They will also attempt to provide answers to some basic questions and issues which customers face when making on-line purchases. The Republic of Serbia has passed a set of laws which comply with the requirements and standards of the European Union. However, it is necessary to continuously conduct the process of education not only of employees in state services and traders, but also consumers in order to raise awareness about the significance and benefits of e-commerce, and above all, customer protection.
\end{abstract}

\section{Keywords:}

Internet sales, European Union, contract, consumer protection.

\section{INTRODUCTION}

One of the main goals and the most important pillars of the European Union is a unique market promoting four freedoms: free movement of people, free movement of goods, free movement of services and free movement of capital. Free movement of goods has contributed to the development of a unique market from which both the citizens and the business sector benefit daily. Today's unique EU market, with the population of over 500 million people, makes buying and selling goods easier and enables consumers to choose from a wide range of high-quality products. Not only do big companies benefit from this, but also, primarily, individuals. The open market will enable a richer, more diverse, and above all, a cheaper offer.

One of the basic questions posed by the market of over 500 million consumers is the question of customer protection. Therefore, this field encompasses a series of regulations which deal with customer protection. 
One of the necessary conditions which Serbia has to meet on its way towards the European Union is the harmonization, i.e. the coordination of its regulations with the EU law. On the one hand, consumer protection is based on the economic principles of the market, and on the other, on the ideas of social justice and responsibility. A high degree of protection is an ideal to which not only consumers, as an economically weaker side, and the state, which is obliged to protect them, strive, but traders as well, given the fact that it ensures them better business results.

In addition to a significant change of legal regulations, a successful implementation of the harmonization process includes substantial investments in the development of economic and industrial infrastructure, as well as in the education of citizens and employees in the state administration and other state bodies.

The aim of this work is primarily to point out the significance of the harmonization of contract law of the Republic of Serbia with the European Union law. The central part of the paperwork the authors deal with the Internet sales and protection of consumers who buy products and services via numerous Internet platforms and, therefore, the authors present the most important regulations governing this area both in the European Union and Serbia. At the same time, they also strive to provide answers to some basic questions and issues which customers face when making purchases on-line.

\section{HARMONIZATION OF THE CONTRACT LAW OF THE REPUBLIC OF SERBIA WITH THE EUROPEAN UNION LAW - CONCEPT, SIGNIFICANCE AND GOALS}

The concept of harmonization (Angleichung, Rapprochement) represents a special procedure or a method whose goal is to harmonize national regulations or the essence of their policies (Vukadinović, 1999, p. 43). Harmonization stands for a long process in which the existing regulations are changed or new ones are made in the EU member states, using different techniques and methods. One of the basic goals of the European Union is the introduction and implementation of the harmonized national regulations in all member states. General legal basis for harmonizing national legal systems is contained in the provisions of Act 3 of the Treaty on Establishing. Harmonization serves as a method to complete communitarian objectives limited by the mentioned provision only to "the establishment of the common market", i.e. resolving or softening differences in national regulations of member states, so that the implementation of such regulations may establish and ensure smooth functioning of the common market. Large differences in national legislations create obstacles to the establishment and existence of the cooperation (Miladinović, 2011, p. 50). Harmonization of legal regulations is one of the necessary conditions for functioning of the common market and better practical application of the fundamental freedoms of the common market.

The harmonization process is not only completed in member states, but it also takes place in the states which have difficulty in getting the membership or which are approaching this union, since the harmonization of national regulations of the candidate states for the membership in the EU is a necessary condition for their acceptance.

The commitment of the Republic of Serbia to join the European integrations has effectuated the issue of the harmonization of its national law with the law of the European Union.

Serbia signed the Stabilisation and Association Agreement in April 2009, which came into effect on September $1^{\text {st }}, 2013$. In June 2013, The Government of the Republic of Serbia adopted the Action plan for the harmonization of the regulations of the Republic of Serbia with the regulations of the European Union, which represents the starting point for harmonization. Serbia obtained 
the status of a candidate state on March $1^{\text {st }}$, 2012. Its prospects for membership will be calculated by the degree of harmonization of its national law with the law of the European Union.

The legal particularism in regulating the matter of contract law represents an obstacle to the integration processes in Europe (Jelinić \& Akšamović, 2010, p. 205). By harmonizing legal regulations, all obstacles encountered during signing an agreement between subjects doing business in different legal, economic and social systems will be removed, which will contribute to the development of international trade and legal certainty achievement. Different contractual rights in member states directly or indirectly reduce the functionality of the common market. Especially, the consumers who are not familiar with different systems of contract law may thus be deterred from completing cross-border transactions (Frenjveš, 2016, p. 4). It is because of this that the harmonization of contract law has become a constant tendency on the part of the national legislators and business people, and a legal doctrine. The biggest obstacles in the path of the cross-border trade are related to differences between states in terms of contract law, especially regarding rules on the conclusion and termination of contracts, or the responsibility for the delivery of faulty products. Both dealers and buyers are faced with such obstacles on a daily basis. They expose dealers to additional costs and make the procedure more complicated; on the other hand, they make the purchase process more difficult for buyers, and often divert them from it, especially when it comes to shopping online.

By harmonizing contract law, legal certainty during the conclusion of legal affairs would be achieved, the procedure itself simplified, the market expanded, and it would lead to numerous opportunities for arranging legal affairs. It would contribute to the development and improvement of this field of law in many ways. All contracting parties would benefit from it - buyers would receive a more diverse and cheaper offer, whereas dealers would benefit from opening of a new large-scale market in terms of new business opportunities.

Due to the aforementioned reasons, but also many more, a set of legal documents has been designed in the European Union with the aim of making a uniform interpretation and implementation of the numerous rules of obligation law, i.e. contract law. The harmonization of contract law is one of the basic tasks of the European Union given the fact that contract law stands for a fundamental assumption in creating a common European market.

The European contract law is not embodied in a single codification. Moreover, a whole series of directives, regulations and other acts dealing with certain legal fields of contract law has been introduced.

On its way to the European Union Serbia undergoes legislative and harmonization processes in the field of contract law and alters its legislature thereby harmonizing it with the requirements and standards of the European Union. The aim of harmonization is not exhausted by modifying, i.e. introducing regulations which comply with the law of the EU. It is reflected in ensuring social and economic conditions for their complete implementation. The advance in harmonization is calculated not only by introducing harmonized regulations but also by proving that they are fully and appropriately implemented. This requires not only the activity of legislative bodies, but also the professional and independent judiciary, efficient state administration and accompanying social infrastructure (Vukadinović, 2009).

In this paper, the harmonization of contract law was discussed only in terms of general issues regarding the concept, significance and objectives. The degree of the harmonization of contract law in our country, regulations introduced, as well as issues arising in practice will be discussed in more detail later in the paper, in the field of consumer protection and only within the range of a narrow field of the contract law - Internet sales. 


\section{CUSTOMER PROTECTION IN INTERNET SALES}

\section{Internet sales - concept and significance}

E-commerce was developed along with the development of information-communication technologies. E-payment was introduced in 1970s. During the nineties, the concept of e-commerce arose and included making different types of business transactions online (selling goods and services, commercial auctions). In the $21^{\text {st }}$ century, there has been a mass production and distribution of electronic devices and services, purchasing and selling products, services and information via a global computer network known as the Internet. In addition to e-commerce, a new concept "Internet sales" appeared, and it stood for a narrower concept than e-business (Prlja et al., 2012).

In a narrower sense, the role of the Internet in contract law is related to the business done online, largely to the contract conclusion and execution. In a broader sense, the role of the Internet refers to all situations in which natural persons and legal entities use the Internet, regardless of whether the contract was concluded or executed via the Internet (Sikirić, 2006).

Despite the resistance and suspicion it faces in our country, online shopping is a necessity imposed by the new information era, offering numerous advantages and benefits compared to the traditional sales. Online shopping is the fastest and cheapest way of shopping for products, as well as the most profitable form of commerce due to the simplicity and low expenses.

It is possible to order almost any product via the Internet. Internet sales most often include books, consumer goods and electronic devices. According to the statistics data, the citizens of Serbia mostly buy at auctions, pay for advertising and computer services, such as hosting and domain registration, and largely buy plain tickets and travel arrangements. The most popular domestic site for e-commerce is a web site for auction sales "Limundo", and an online store with fixed prices "Kupindo".

Internet sales have many advantages from the standpoint of the consumers: buying goods from home, quicker delivery, lower price of products, avoiding the pressure of sellers, a greater selection of products and shops, easier access to information, easier price comparison (Stojanović, 2011).

According to the Institute of Statistics 2015 data, more than 1.2 million persons in Serbia made their purchases via the Internet, whereas in 2013, 900,000 people in Serbia shopped online, which demonstrates an increase of 30 percent for the period of two years. However, Internet sales in Serbia are still below the European average. 57 percent of the Internet users in our country have never shopped for goods or services online (Kovačević et al., 2015). Some of the main reasons include lack of knowledge of the process and protection mechanisms, fear of losing personal data, misuse and fraud.

This poses the questions of legal certainty, consumer protection, and above all, the harmonization of regulations referring to this field, which represents a guarantee for smooth functioning of cross-border trade. The benefits of the Internet are significant and global, and nations should not allow national laws and local regulations to obstruct the thriving of the global Internet (Gillies, 2001).

An increasing number of consumers making online purchases and e-payments has imposed the need for a precise definition of numerous material and process rules which regulate the matter of concluding e-contracts, but which will, above all, be harmonized with the law of the European Union. Numerous illegal activities in e-commerce, such as the misuse of electronic data, electronic frauds, phishing on the Internet, as well as other ways of doing harm in the Internet sales, such as undelivered goods, insufficient quality, etc., require a regulation which would enable a 
high level of legal certainty and protection (Prlja et al., 2012). Internet contracts, also, pose difficulties caused by the fact that the Internet works on the basis of logical rather than geographical locations and that consequently neither the parties nor the performance of the contract are easy to locate (Schu, 1996, p. 94).

\section{Consumer protection in Internet sales in the European Union}

The Law on Consumer Protection in the European Union was developed as a by-product of the formation of the common European market (Lazić, 2006, p. 250). Maastricht and Amsterdam agreements had laid the foundation for the European policy of consumer protection, defined its aims, as well as the fundamental rights of consumers.

Article 169 of the Treaty on the Functioning of the European Union has set a legal basis for a whole range of activities in the field of consumer protection. The European Union has introduced a series of regulations which guarantee consumer protection, their right to information, education, health protection, safety, protection of economic and legal interests, thereby reaching the highest degree of legal development and consumer protection. Several dozen directives, which, directly or indirectly, regulate consumer rights, represent the most important source of the European consumer law. The E-Commerce Directive addresses new rules and responsibilities on the Internet and also strives to arrive at a uniform regulation of numerous other legal issues on a horizontal basis throughout Europe (Lehamann, 2001, p. 105).

One of the most important initiatives of the European Union in the field of consumer protection is The Directive 93/13/EEC on the unfair contract terms. The provisions of this directive limit the dealer's freedom of contracting, preventing them from imposing contractual provisions which this directive considers unfair for the consumer.

The Directive 97/7/EC on the distance contracts regulates consumer agreements concluded without the physical presence of both the dealer and the consumer. The directive sets the obligation of the precontractual information the dealer is required to provide to the consumer prior to the conclusion of the contract.

The Directive 99/44/EC on the sales of goods regulates the contractual relationship between the dealer and the consumer in case of the agreement on the sales of goods. The main objective of this directive is to completely legally ensure that the consumer receives the product which fully conforms to the concluded consumer contract from the dealer.

The Directive 2011/95/EC on the general product safety provides for a general safety system of products, according to which all products placed on the market have to be in accordance with set norms regarding the information of consumers, measures for preventing safety threats, and product safety monitoring. According to this directive, the manufacturer is obliged to launch only safe products. In case a product poses a serious threat that requires a quick response, a member state must immediately inform the Commission about it via RAPEX, a system for rapid exchange of information between the member states and the Commission.

Strict safety standards which apply to products in the common market, owing to which faulty products are quickly withdrawn from the market, guarantee efficient consumer protection.

Distant advertising regarding financial services for consumers is regulated by the Directive 2002/ 65/EC. 
The Directive 2005/29/EC on unfair business practice (of the dealer with respect to the consumer) prohibits misleading and aggressive practice, "tricks" (such as pressure sales, misleading marketing and unfair advertising). It contains criteria for determining aggressive business practice (harassment, coercion and undue influence). The Directive 2006/114/EC on misleading and comparative advertising prohibits misleading advertising. It also sets conditions under which comparative advertising is permitted.

The Directive 2011/83/EU on consumer rights has increased consumer rights, set rules for providing consumers with information, regulated the right to withdraw and harmonized certain contractual provisions.

The European Union protects consumer interests particularly in the field of distance contracts. The European Commission has suggested the guidelines for good practice of doing business on the Internet and rules for all kinds of non-cash payment. In 2015, The European Commission announced a strategy for a unique digital market in Europe. It created 16 initiatives aimed at creating a unique and connected digital market and encouraging e-commerce.

Even though the majority of legal acts of the European Union in the field of legal protection of consumers is related to material-legal issues, the procedural aspects are not ignored. The Directive $27 / 98 / \mathrm{EU}$ is intended to reach the efficient consumer interest protection. It imposes an obligation on member states to foresee in their legal system the possibility for consumer protection organizations to file a complaint in favour of consumers (Galič, 2005, p. 112).

The Regulation No.44/2001 on jurisdiction and enforcement of judgements in civil and commercial matters (The Brussels Regulation) provides for special decisions on the international jurisdiction in consumer disputes. The Brussels Regulation applies only on condition that the defendant in court proceedings is a person with the residence, i.e. base in the European Union (article 4 of the Brussels Regulation). The Brussels Regulation sets a general rule that it does not matter whether the prosecutor has a domicile in the European Union or not. However, in case the Brussels Regulative exceptionally binds jurisdiction to the prosecutor's state of residence, and if the prosecutor doesn't have a residence in the European Union, the court of the state in question shall not be able to claim the Brussels Regulation as a source (Galič, 2005, p. 117).

The first step in the legal regulation of e-payment was made by the United Nations Commission on the International Trade Law (UNCITRAL) by adopting the Model Law on Electronic Commerce in 1996, and the Model Law on Electronic Signatures in 2001.

In 1997, the European Union adopted the European Initiative in the Sector of Electronic Business, followed by the Directive on Electronic Signatures in 1999, and the Directive on Electronic Commerce in 2000 .

In the late 20th century, leaders and administrators of the European Union noticed problems and a need to deal with numerous issues arising from the intensifying use of the Internet in doing business. The European Parliament adopted the Directive on Electronic Money - Directive 2000/46 EC, as well as the Directive 2007/64 EC. In 2009, the European Parliament adopted a new directive, Directive 2009/110 EC which has eliminated the shortcomings of the first one and now stands for the existing directive which has regulated the issues of electronic money and a regulatory framework for the harmonization of the electronic money market in the EU member states.

In case of a dispute, assistance is provided in its rapid and efficient resolution via alternative ways of dispute resolution and European centres for consumer protection. In May 2013, the Directive 2013/11 
on the alternative dispute resolution and the EU Regulative No.524/2014 on the online dispute resolution were introduced. They have enabled consumers to take simpler, more efficient, faster and cheaper ways of resolving disputes, i.e. without going to court. Alternative methods of resolving disputes have enabled consumers and dealers to resolve all kinds of disputes via various entities, such as mediators, arbitrators, ombudsman, individuals, appeal committees, which entirely operate online. This highly reduces costs and time regarding disputes between consumers and dealers who are far away from each other, which is often the case in the Internet sales. Since 2016, an Internet service, the European electronic platform, has been available for consumers in the European Union via which they can file a complaint in some of the official languages of the European Union. This platform connects National bodies for alternative dispute resolution and enables fast and efficient resolution of disputes within 90 days.

The European small claims procedure has been available since 2009 and it is applied to all civil and trade matters in which the value of claims is less than 2,000 euros (the amount will be increased to 50,000 euros from 2017). No lawyers are needed, and judgements are recognized and enforceable in all EU member states.

The European Consumer Centres Network "ECC-Net" was formed to provide citizens with free advice. Two thirds of cases resolved by the centres from the ECC-Net had a positive outcome (ECCNet, 2015). The program of the EU action in the field of consumer protection policy consists of the European strategy for consumers in accordance with the EU's growth strategy Europa 2020 and the program for consumers 2014-2020. The European strategy for consumers has several objectives: better understanding of consumer rights, better enforcement of regulations in the field of consumer protection, integration of consumer interests in key policy sectors, and strengthening of consumer role.

The European Parliament has introduced the Regulation (EU) No.254/2014 on a multiannual program for consumers for the period from 2014 to 2020 .

The network for consumer cooperation and protection connects competent authorities of all member states to detect, research and stop illegal business practice. It is also used for monitoring the market and for "system checks" of web pages and their compliance with the EU rules on consumer protection.

The campaign for raising awareness on the consumer rights organized by the Commission lasted from spring 2014 to early 2016, during which the citizens were being informed about their rights within EU regulations for consumer protection and directed to right places where they could get advice or help in case they had any questions or problems. The aim of the campaign was to raise general knowledge of dealers and consumers about the consumer rights in the European Union.

The European Union has organized activities for educating consumers on different levels, such as gradual introduction of consumer education into primary and secondary school curriculums. The European school calendar (Europa Diary), a school diary designed for secondary school students contains, among other things, information on their consumer rights. The Commission has conducted an experimental program to educate teachers and support the establishment of graduate studies of consumer protection policy.

\section{Legal Framework of the consumer protection in Internet sales in Serbia - degree of harmonization with the European Union Law}

The obligation of the legislature to adopt specific regulations to secure a high level of consumer protection and their safety has its legal basis primarily in the Constitution of the Republic of Serbia. 
Article 90 of the Constitution of the Republic of Serbia guarantees consumer protection and explicitly prohibits actions directed against consumer health, safety and privacy, as well as all other dishonest activities in the market. By signing the European Union Stabilization and Association Agreement, Serbia has committed itself to harmonize the standards of consumer protection in Serbia with the EU standards. Therefore, it is obliged to ensure the policy of active consumer protection, harmonization of legislature on consumer protection, efficient consumer protection, control over the implementation of rules by competent authorities, access to justice in case of disputes, as well as the exchange of information on dangerous products (Article 78 of the European Union Stabilization and Association Agreement).

The process of harmonization is not limited to the EU member states only, but it is much wider, given that the member states aspiring to gain associate or full membership are obliged to conduct the harmonization of their own national legal system with the legal system of the European Union (Stanivuković, 2001, p. 70). An EU candidate country needs to adopt, implement and enforce all current EU rules and legislation as a necessary condition for acceptance (EU Info Center, 2014, p.11). Directives are binding, as to the result to be achieved, but leave to the national authorities the choice of form and methods. National legislators must adopt a transposing act or national implementing measure to transpose directives and bring national law into line with their objectives (European Commission, 2013, p. 5).

The Law on Electronic Signature was passed in 2004 and it represents the first regulation to deal with some of the aspects of e-commerce. It regulates the use of e-signature in legal affairs and actions, business, rights and obligations regarding e-certificates (Article 1 of the Law on Electronic Signature). It guarantees the validity and probative value of an electronic document. The Law on Electronic Signature is in compliance with the EU Directive 1999/93 EC on electronic signatures, which was adopted on December $13^{\text {th }}, 1999$ and came into effect on January $19^{\text {th }}, 2000$.

The Law on e-Commerce, which was passed in 2009, equalized e-business forms with traditional ones. This law defines the agreement on electronic form as an agreement which is concluded, sent, received, terminated, accessed and displayed electronically using electronic devices (Article 3, Paragraph 7 of the Law on e-Commerce). The law sees electronic trade of goods and services as a form of distance trade in terms of the Trade Law, thereby equalizing it with traditional trade. The Law on e-Commerce is compliant with the EU Directive 2000/31/EC on electronic commerce.

The legal framework of consumer protection in Internet sales is represented by the Law on Consumer Protection which provides for the protection of consumers in exercising their rights from distant contracts, i.e. online purchases. The law regulates the rights of the consumers, conditions and means of their protection, rights and obligations of organizations acting in order to achieve protection, out-ofcourt resolution of consumer disputes, and the rights and obligations of the state authorities regarding consumer protection.

The Law on the Protection of Financial Service Consumers in distance contracting enhances the protection of the financial service consumers in the Republic of Serbia, and regulates financial consumers' right to information both in the precontractual stage and the period after the conclusion of the contract, the right to withdraw from distance contracts (as a rule, within 14 days), the right to terminate the contract, the right to protect themselves from services which were not asked for, and other rights of the financial consumers in distance contracting, as well as the protection of rights and interests of those consumers and control over the implementation of the provisions of this law. Its provisions are also related to providing services via the Internet, e-mail, mail or other means of distance communication. The Law on Financial Consumer Protection in distance contracting is compliant with the legal regulative of the European Union - primarily the Directive 2002/65/EU. 
The Law on Consumer Protection and its amendments regarding the protection of consumers in exercising rights from the distance contracts, i.e. doing online purchases, is certainly the most significant law in the field of consumer protection in Internet sales. The Law on Consumer Protection defines a distance contract as a contract concluded between the dealer and the buyer within the framework of the organized sales or providing distance services without the presence of dealers and buyers, exclusively by using one or more means of distance communication upon the time of the conclusion of the contract, including the moment of the conclusion itself.

The Law protects consumer rights when they make purchases on the basis of their order, via e-mail, the Internet, television sales, as well as other "distance sales", i.e. its provisions are related to purchasing goods or services from web pages and ordering via e-mail.

The provisions of 15 key European directives in this field have been implemented and a legal framework which enables the harmonization of consumer rights in Serbia with the European standards was established.

The Law on Consumer Protection is in compliance with the European legislation, primarily the Directive 2011/83/EU on the consumer rights and Directive 2013/11/EU on the alternative resolution of consumer disputes, which is of key importance in enhancing out-of-court dispute resolution.

The Rulebook on the activities of the body for out-of-court resolution of the consumer disputes has been adopted. It defines conditions for out-of-court resolution of consumer disputes, with the aim of ensuring that the resolution process is independent, unbiased, transparent, efficient, fast and fair. The adoption of this rulebook was placed under the jurisdiction of the minister. The legal theory reasonably remarks that this is strictly a political body which should not be entrusted with such authority regarding such a delicate issue as consumer protection in relation to out-of-court dispute resolution (Petrović-Tomić, 2014). The solution could be the adoption of a special law which would regulate this matter in an integrated manner.

In cases when the purchases are made via the Internet platforms Limundo d.o.o. and Kupindo d.o.o., we should mention the Terms of Use of the Internet platforms of Limundo d.o.o. society, which represent the provisions of the contract between this society and each individual member, and they are primarily aimed at e-commerce. The terms set the rules of the Limundo and Kupindo platform markets, obligations of members, the way of the contract execution, as well as the alternative ways of resolving disputes.

The adopted strategy of consumer protection for the period from 2013 to 2018 is in accordance with the requirements of the European Union for creating a better environment for consumers. Therefore, in this respect, objectives and activities of this strategic document were proposed. The main objective set by this document is to ensure a high level of consumer protection in the Republic of Serbia by 2018, as well as to improve the system of consumer protection in line with the standards and practice of the European Union. Having conducted the screening for Chapter 28, which relates to the consumer and health protection, it has been determined that there is a high level of harmonization with the EU regulations in this field. The European Commission uses the screening method to verify whether the regulations of a candidate state are compatible with the requirements of the European Union and to suggest harmonization if necessary (Simović, 2014, p. 466).

However, as it was mentioned earlier in the paper, it is not enough just to pass a law and bylaw regulations which enable its implementation. In practice, numerous problems arise during the implementation of these laws, due to the lack of knowledge of the citizens and inadequate education of employees in competent state authorities. 
Supported by the European Union, the state authorities have conducted a number of projects with the same aim and have also issued numerous publications. Therefore, The Development of e-Business project, financed by the European Union and implemented in cooperation with the Ministry of Trade, Tourism and Telecommunications and the Ministry of Economy, had an aim to inform consumers making online purchases about their rights. During the project, a total of 66 small and medium enterprises and entrepreneurs, who reached high standards in the field of e-business, received a trust mark (e-Trustmark). e-Trustmark is a label, picture or a logo in e-commerce displayed on the website of an organization confirming that the website is safe for making purchases. The purpose of the eTrustmark label is to enhance the quality of the national Internet stores and establish trust between the Internet dealers and consumers making online purchases. Numerous workshops and training sessions on e-business and e-commerce have been organized for more than 700 representatives of the small and medium enterprises, all with the aim of recognizing the importance of e-business for increasing competitiveness and decreasing operating costs. However, bearing in mind time the young spend on the Internet and the buying scope via numerous Internet platforms, workshops and seminars should be initiated as early as the secondary school in order to get them acquainted with their rights when shopping and warn them about the risks and dangers due to carelessness and lack of information. The young are very active especially when it comes to the social network Facebook and often use it to make online purchases, at the same time being exposed to a myriad of frauds.

In order to increase confidence of e-consumers in e-commerce, in cooperation with the Sector for consumer protection and the Ministry of Trade, Tourism and Telecommunications, a specialized Internet platform E-dukator was developed, the first of a kind in Serbia, with the aim of informing and educating the citizens of Serbia about their consumer rights for safer online shopping. The centre for the development of e-commerce and consumer protection on the Internet has also been founded.

\section{COMMON CONCERNS, I.E. FREQUENTLY ASKED QUESTIONS IN INTERNET SALES}

The study conducted within the project "The Development of e-Business" has showed that 91 percent of the citizens do not know their rights in online shopping. It is exactly one of the key reasons why Serbia still takes the last place in e-commerce.

Further in the text, the authors attempt to provide answers to some frequently asked questions and concerns arising during online shopping. All these answers comply with legal regulations, however, due to the diversity of these regulations, only experts can consider them as a whole. Direct participants in online shopping do not understand them, and therefore often violate them accidentally.

\section{Obligations of Internet vendors}

According to the Law on Consumer Protection, the vendor is obliged to make available "precontractual information of consumers" whereby they have to inform the consumer in a clear and understandable way about their business address, selling price, conditions, time frame and procedure for exercising the right to withdraw from the contract.

The Directive 2011/83/EU on consumer rights stipulates the obligation to inform consumers about twenty elements in concluding distance contracts. Since the vendor is obliged to inform the customer about a myriad of circumstances, legal literature often stresses the danger from the so-called 
"information overload" which could result in a opposite effect, i.e. customers may lose interest and overlook information that is crucial for them (Petrić, 2015, p. 731). The Directive 97/7/EEC on consumer protection in concluding distant contracts regulates the field of protection of the consumers, goods or distant services starting from the requests for payment of unsolicited goods and aggressive selling methods of dealers. The burden of proof shifts to the dealer or service provider, given the circumstances that the consumer does not control the means of communication (Perinčić, 2014, p. 54).

The vendor is obliged to deliver goods within 30 days (Article 32 of the Law on Consumer Protection) and is responsible for the conformity of goods within 2 years. The buyer has the right to file a complaint about goods which the vendor has to respond to within maximum of 8 days and has a deadline of 15 days for removal of any defects (in case of furniture and technical goods the deadline is 30 days). In case the vendor does not respond within this deadline, the buyer has the right to address the market inspection. However, a market inspector can only order the vendor to respond to the buyer's complaint, but not to affect the content of the complaint itself, i.e. to order them to resolve the complaint.

The Law on e-Commerce stipulates that the provider of services in distance contracts is obliged to provide a potential consumer with the data on general terms and conditions, contractual provisions, procedure of concluding these contracts, and the codes of conduct (Article 12 of the Law) in a clear, comprehensible and unambiguous manner. The service provider is obliged to confirm the receipt of an e-mail containing an offer or acceptance without delay, in an electronic form, in a separate e-mail (Article 14, paragraph 1 of the Law).

Processing of personal data must be necessary, fair and lawful. It is prohibited to use and transmit them for purposes other than those originally mentioned (Neacsu, 2016, p. 307).

The provision on setting activities whose conduction does not require making records of the turnover using fiscal cash register defines that online retailers are not obliged to issue fiscal receipts during sales. In this sense, the opinion of the Ministry of Finances No. 430-00-1436/2011-04 from March 23 ${ }^{\text {rd }}$, 2011 was stated.

\section{Return of inappropriate goods}

The consumer's right to withdraw from the contract is one of the most significant achievements of the Consumer Law in the European Union. Even though the right to withdraw is against the contract law principle pacta sund servanda, this institute was introduced to protect customers (Jovanović-Zattila, 2015, p. 755). Owing to this institute, the consumer is given the opportunity to reconsider and review the purchased item, to consider all circumstances and reach a final decision. This is particularly important for the products bought online, since, on the one hand, the consumer may reach an irrational decision due to a strong impression created under the influence of advertisements, and on the other, there is no possibility to physically check the quality of the product. The Directive 2011/83/EU on the consumer rights provides for a unique deadline of 14 days to withdraw from contracts concluded outside business premises and distant contracts. It is considered that the dealer has fulfilled the obligation to inform the consumer about the right to withdraw if he has appropriately filled in the standard form with information and has submitted it to the consumer. This institute has also been envisaged by the Law on Consumer Protection and the Law on Financial Consumer Protection.

The vendor is obliged to provide the consumer (via e-mail or home address) with a form for cancellation and explain the details of the procedure. The consumer has a deadline of 14 days to change their 
mind and cancel the purchase without any explanation. If the consumer wishes to use this right, they are obliged to inform the vendor via the cancellation form within 14 days. The consumer is obliged only to cover the costs of returning goods. The vendor is obliged to make a refund within 3 days. It is not possible to return opened audio and video files, as well as computer software.

\section{Cases when a product is faulty or incomplete}

The vendor is obliged to deliver goods which are in conformity with the contract. In case the delivered goods do not conform to the contract, the consumer, who has previously informed the vendor on non-conformity, shall be entitled to demand from the vendor to remove the non-conformity, free of charge, by repair or replacement, i.e. to demand corresponding price reduction, or terminate the contract regarding faulty goods if a repair or replacement is not possible. If the non-conformity occurs within 6 months from the date of the purchase, the consumer shall be entitled to choose between demanding the removal of non-conformity, seeking corresponding price reduction or terminating the contract (Article 50 and 52 of the Law on Consumer Protection). In the first six months, the consumer has the right to have the goods replaced or repaired, or the amount paid refunded, regardless of the current price. The repair of goods is possible only with the consent of the consumer. If the vendor refuses to accept the complaint, i.e. if it is not possible to be filed due to distance, the consumer shall send it via registered mail or in the electronic form to the vendor's email. In case the vendor does not respond to the complaint, the next step is addressing the Regional Counselling for consumer protection. If the consumer fails in exercising their rights this way, they have the right to address the competent court and file a lawsuit. If the non-conformity appears within 6 months from the purchase, it is presumed by the law that the goods were faulty at the time of the delivery. The vendor shoulders the burden to prove the opposite. Trade disputes valued up to RSD 500,000 are not subject to the court fee.

The new Law on Consumer Protection is harmonized with the European regulations and practice of the non-intervention of the state in the relation between the vendor and the consumer. It is a civil law relation, and as such, it cancels the role of a market inspector in resolving individual consumer disputes.

The citizens of the European Union are more protected from frauds since they can use the Internet platform of the European Commission where they can start a process of resolving disputes with Internet vendors out of court.

In case of purchases made via Limundo.com and Kupindo.com platforms, consumers may use additional and modern ways for claiming their rights. The terms and conditions of Limundo d.o.o. Internet platform society define that Limindo d.o.o. may voluntarily mediate in resolving possible issues in case a dissatisfied member files a complaint within a stated deadline. If a product is faulty, the consumer may file a complaint within three days from the payment of funds to the LC account. Limundo d.o.o. is authorized to reach a decision either in favour of the vendor or the buyer. Furthermore, it has the right to make a refund for a purchased item, i.e. make a payment to the buyer's account, but only if the buyer submits the evidence that the item has been returned to the vendor (Article 14.4 of the Terms and Conditions). Since payment is done via the LC account, and funds remain there for three days prior to being transferred to the vendor's account, in case the buyer files a complaint about the item not being delivered or not being in the specified state, no later than 3 days from the payment of funds to the LC account, the complaint procedure which allows the buyer to exercise their rights this way, is started. The ultimate sanction which Limundo d.o.o. may apply is the suspension of the vendor membership status if the vendor does not cooperate with the buyer (Article 11.5 of 
the Terms and Conditions). The Limundo company has formed a special team composed of lawyers, psychologists and IT experts, whose task is to prevent frauds. Moreover, there is a special system of Limundo protection (protection of buyers and dealers) which represents a form of protection in situations when the buyer did not get a paid item, i.e. the dealer did not receive the money for the item sent to the buyer. In such a case, the Limundo company pays the aggrieved member up to RSD 10,000, and later claims its right for compensation from the person who committed the fraud. During the period from September 2014 to September 2015, Limundo paid its users RSD 138,372 for protection. In cooperation with the police, the Department for High Technology Crime of the Ministry of Interior of the Republic of Serbia and the prosecutor's office collect evidence and submit criminal charges. Limundo assumes all duties and covers costs regarding writing and filing criminal charges, establishes contacts and holds consultations with competent authorities. This is a very important solution due to the existence of "consumer apathy", i.e. consumers generally do not initiate court proceedings if the value of a dispute is relatively small, because, from consumers' point of view, that value does not justify the initiation of court proceedings which could take a long time and cost a lot (Karanikić-Mirić, 2014, p. 60). The first verdict which sentenced the person who committed a fraud via Limundo portal to 6 months in prison suspended for 2 years, was reached in 2016. When the fraud happened in 2014, the company Limundo first paid compensation to all claimants, and then filed a lawsuit against the person who committed a fraud, which resulted in the abovementioned judgement in favour of the company Limundo. The Limundo team analyses each case of fraud in particular and then improves the whole system, thus making it safer and stronger.

However, despite positive experiences, the Association for Consumer Protection has recorded a myriad of negative experiences and complaints. The majority of complaints are related to purchases made via Facebook, Kupindo, Limundo and similar websites, i.e. to purchases made between natural persons. Namely, the Law on Consumer Protection is not applied to contractual relations of two natural persons, but when a contract is concluded between the consumer (natural person) and the vendor (legal entity, i.e. entrepreneur). Persons who purchase items via Internet platforms or Facebook may exercise their rights in accordance with the Law on Consumer Protection only if they purchase from vendors registered as legal entities or entrepreneurs, i.e. vendors that have clearly visible labels to prove that.

\section{How to make safe online purchases}

The first step towards the safe Internet sales is to check the Internet vendor. The Internet vendor is considered safe if their webpage contains their basic information, terms and conditions of sales, detailed data on products, prices, data on the method of payment and applied standards for ensuring the safety of transactions and personal data, information about consumer rights, data on licences for carrying out operations and dealers' membership in professional associations. If a certain question cannot be answered or the answer is unclear, one should not shop there. If the Internet vendor does not provide the address, it may be the indicator that the vendor is not reliable. If shipping costs are not clearly specified, it may indicate the price will be much higher than expected. One should be very careful when it comes to personal data and leave only those that are necessary for making a purchase. Most problems in online purchases are due to the carelessness of consumers themselves.

As for making purchases via websites such as Kupindo, Limundo, as well as via social networks such as Facebook, one should check the person offering items for sale, how long they have been selling items this way, as well as the reviews of other buyers. 
Domestic legal entities and entrepreneurs, along with branches of foreign companies, need to be registered in the book of registry of the Business Registers Agency.

\section{Payment in online purchases}

Online shopping in Serbia had functioned for years prior to the adoption of the Law on Payment Services and introducing the institute of electronic money which enabled the payment of goods and services via mobile phones. The Law on Payment Services was passed on October $1^{\text {st }}, 2015$ and it has regulated the use of electronic money and new organization of the payment system, hence modernizing and enhancing the payment services not only in the country, but also with countries abroad. It has also regulated online payment, and primarily, the implementation of the EU Directive 2000/46/EC on taking-up, pursuit and prudential supervision of institutions issuing e-money was carried out. This law has enabled Serbia to be easily included in the European payment system after the accession to the European Union. Amendments to the Law on Foreign Exchange Operations have allowed the citizens to make payment transactions with foreign countries via domestic e-money and payment institutions, not only via foreign ones, such as PayPal. The law stipulates that the citizens of Serbia may make payment transactions with foreign countries either via a payment institution or an authorized public postal operator. The Law on Foreign Exchange Operations could be improved in order to introduce mechanisms to enable local traders to sell to the buyers outside of Serbia, with payment in foreign currency. This change would have a positive impact on the growth of the foreign exchange inflow in the country.

There are multiple methods of payment in online shopping. In domestic online shops, payment can be done via standard payment orders which are debited against clients' current accounts, or in cash upon delivery. In foreign online shops, it is possible to pay using wire accounts or credit cards. They are designed exclusively for online shopping and people make payments to these cards when they intend to make online purchases.

The most common method of online payment is by credit and debit cards. Almost all banks operating on the territory of Serbia offer their clients cards which are designed exclusively for shopping on domestic and foreign websites (for instance, VISA VIRTUON).

The PayPal payment system was introduced in April 2014. As a mediator between the bank and the vendor making transactions without issuing data on the card, it reduces the risk of misuse and increases the safety of online shopping. PayPal is a system for electronic payment which enables a fast and secure money transaction online (receiving and payment), via mobile phones and in stores. The advantage of this system is that the buyer adds money to their account using their banking cards, then makes payments through it, without revealing data (such as the card number) to the vendor. PayPal turns the email address into an electronic wallet and enables its users to receive or send money to any PayPal user. All they need to do is specify the address and the amount, and the money transfer is done in a few minutes. In Serbia, the option of receiving money has officially been available since 2015, therefore enabling small stores and individuals to do business with 165 million active PayPal users in 203 countries worldwide. However, using PayPal to shop for items on domestic websites is not possible, since the National Bank of Serbia does not allow domestic payments in foreign currency, and PayPal does not have the option for payments in dinars.

In case of purchases made via Internet platforms Limundo.com and Kupindo.com, there is a special payment system known as Limundo Cash (LC). It serves as a mediator for transferring money 
from the buyer to the vendor for purchases made via these platforms. By transferring funds to a special account created by Limundo d.o.o. for LC purposes only, the buyer authorises Limundo d.o.o. to transfer the paid amount for a purchased item to the vendor's account, no later than three working days from the payment.

\section{CONCLUSION}

In Serbia, in the field of contract law, the process of harmonization is going in good direction. A series of laws and other bylaw regulations regarding the requirements and standards of the European Union have been passed. Naturally, it is still necessary to change a large number of regulations, such as regulations on the customs, tax, republic administrative fees, information safety, and electronic archives. Furthermore, considering the Law on Obligation, as the fundamental legal source for editing contract law, when reaching the new Civil Code, it should undergo certain changes in order to be harmonized with the international sources in this field (the concept of fundamental breach of contract, periods of prescription, etc.) (Ćirić \& Cvetković, 2006, p. 271).

The European Commission accepts the principle of a "targeted" harmonization whose degree will differ from case to case and the benefit of the consumer, without the application of the automatic and unconditional harmonization. Regarding the policy of the European contract law for the protection of consumers, it used to be characterized by the requirements for minimal harmonization for a long time. With the exception of the Directive on liability of the manufacturer for faulty products, all other directives in the field of the consumer protection were based on the requirements for minimal harmonization. However, the last decade of the development of the European law for consumer protection has been marked by a radical shift from the requirements for a minimal to the requirements for a maximal harmonization (Gomez \& Ganusa, 2011).

In distance contracts, especially in online shopping, a complete harmonization is necessary to enhance the creation of a unique market. A series of regulations has been reached in the European Union guaranteeing consumer rights and protection of their legal and economic interests, thereby reaching the highest degree of law development and legal consumer protection. That is why it is essential to conduct a rapid and efficient harmonization with the regulations of the European Union. The Republic of Serbia has passed a set of laws and other bylaw regulations which comply with the requirements and standards of the European Union in the field of e-business and consumer protection.

Despite a tremendous potential for the development of economy, the increase of employment and competition, as well as for facilitating everyday life, e-business is still in its infancy. The "Global ecommerce development index for 2015" study states that Serbia ranks last, since as a country it does not have a prepared plan for a further development of e-commerce. Successful business in modern economy is determined by the ability of an enterprise to meet the demands of the market, to track changes which are becoming more and more frequent and dynamic (Stanisavljev et al., 2012, p. 1). On the one hand, e-commerce allows a fast track of those changes, but on the other, it is one of those demands.

Naturally, the efforts of state authorities and political elite cannot be argued. The Internet platform named "E-dukator", which enables citizens to find answers to all queries related to online shopping, arose within the "Development of e-business" project, which is supported by the European Union. However, consumers still regard e-commerce with suspicion and resistance, and traders do not have a clear digital strategy and developed approaches to e-commerce. 
As already stated in the paper, introducing legal regulations is just not enough, but it is their efficient implementation and application by citizens and authorities that is of great importance. The aim of harmonization does not imply only formal harmonization of the national regulations with the European Union Law (formal harmonization), but above all, the creation of the appropriate conditions for their implementation, which can be achieved by the independent and authoritarian judiciary and state administration (substantive, functional harmonization) (Vasiljević, 2009, p. 372). It is necessary to work on the strengthening and affirmation of alternative mechanisms for dispute resolution, which cannot "come to life" overnight. The development of the system for out-of-court resolution of disputes in this field disburdens courts, and the work of associations for consumer protection contributes to strengthening the consumer impact. By joining the RAPEX system for rapid exchange of warnings and information on dangerous and unsafe products, the general safety level of products has increased, thereby reducing costs in the health sector, i.e. costs of treating injuries and illnesses caused by using unsafe products.

At the same time, bigger and more systematic investments in the development of the non-governmental organizations are necessary, primarily associations and unions for consumer protection, especially regional consumer centres, both in terms of enhancing their material and human capacities, and in their affirmation as the address for filing consumer complaints (Lazarević et al., 2013).

There is a problem with law enforcement, especially by the government due to the lack of the professional staff. In addition to passing laws, it is necessary to conduct an equally long and tiresome process - the process of education of employees in state services, traders, but also consumers in order to foster awareness of the significance and benefits of e-commerce, and above all, customer protection.

The implementation and enforcement of the consumer and health protection policies require adequate administrative capacities and infrastructure on a national, regional and local level. The Republic of Serbia will have to educate independent administrative structures with executive authority which will further enable the efficient monitoring of the market and enforcement of regulations.

Harmonization is an extremely long and complicated process, and Serbia is not even close to its termination. The European Union law is not a completely built and integrated system, but the legal system still under construction, which includes, in addition to 20,000 different regulations of secondary legislature, a few thousand decisions of the Court of Justice and the Court of First Instance (Vukadinović, 2009). According to the experience of the member states, harmonization has proven to be a very complex task because the European Union Law shows, to a certain extent, the characteristics of the Case (Kovačević-Kuštrimović \& Lazić, 2007).

However, the issue of full harmonization with the EU law is not a burning issue to the extent the issue of ensuring functional mechanisms for the implementation of the harmonized norms is, since otherwise, well-harmonized legislation remains only on paper. 


\section{REFERENCES}

Ćirić, A., \& Cvetković, P. (2006). Usaglašavanje poslovnog ugovornog prava Srbije sa međunarodnim izvorima. Sa naučne konferencije Funkcionisanje pravnog sistema Republike Srbije, May 18, 2006 (pp. 262-274). Niš: Pravni fakultet u Nišu. In Serbian.

European Commission. (2013). The European Union explained - How the European Union works. Luxembourg: Publication office of the European Union.

European Union Information Centre. (2014). 35 Steps towards the European Union. Belgrade: EU Information Centre.

Frenjveš, A. (2006). O stanju harmonizacije ugovornog prava u Evropskoj uniji. Revija za pravo osiguranja, 1-2, 1-9. In Serbian.

Galič, A. (2005). Procesnopravna zaštita potrošača u pravu Evropske unije. Sa naučne konferencije Pravni sistem Republike Srbije - usaglašavanje sa pravom Evropske unije, May 17, 2006 (pp. 111-124). Niš: Pravni fakultet u Nišu. In Serbian.

Gillies, L. (2001). A review of the new jurisdiction rules for electronic consumer contracts within the European Union. Journal of Information, Law \& Technology. Retrieved April 19, 2017, from https://www2.warwick. ac.uk/fac/soc/law/elj/jilt/2001_1/gillies/.

Gomez, F., \& Ganusa, J. (2011). An Economic analysis of harmonization regimes: full harmonization, minimum harmonization or optional instrument. European Review of Contract Law, 7(2), 275-294.

Jelinić, S., \& Akšamović, D. (2010). Ugovorno pravo Evropske unije na prekretnici. Zbornik Pravnog fakulteta u Zagrebu, 60(1), 203-254. In Croatian.

Jovanović-Zattila, M. (2015). Pravo potrošača na povlačenje iz ugovora. Zbornik radova Pravnog fakulteta u Nišu, 70, 755 -765. In Serbian.

Karanikić-Mirić, M. (2014). Kolektivna zaštita potrošača u srpskom pravu. Anali Pravnog fakulteta Univerziteta u Zenici, 14, 57-83. In Serbian.

Kovačević, V., Pavlovć, K., \& Šutić, V. (2015). Upotreba informaciono-komunikacionih tehnologija u Republici Srbiji, 2015. Beograd: Republički zavod za statistiku. In Serbian.

Kovačević-Kuštrimović, R., \& Lazić, M. (2007). Građanski zakonik Srbije i pravo Evropske unije. Pravni život, 11, 409-428. In Serbian.

Lazarević, N., Đurović, M., Lazarević, M., \& Đinđić, M. (2013). Studija potrošačke politike u Srbiji: ka evropskom nivou zaštite potrošača u Srbiji. Beograd: Centar za evropske politike. In Serbian.

Lazić, M. (2006). Harmonizacija evropskog građanskog prava i prava Republike Srbije. Sa naučne konferencije Funkcionisanje pravnog sistema Republike Srbije, May 18, 2006 (pp. 246-260). Niš: Pravni fakultet u Nišu. In Serbian.

Lehamann, M. (2001). Electronic commerce and consumer protection in Europe. Santa Clara High Technology Law Journal, 17(1), 101-114.

Miladinović, S. (2011). Pravo na razliku i organizovana harmonizacija ugovornog prava. Strani pravni život, 3, 46-57. In Serbian.

Neacsu, N. (2016). Consumer protection in electronic commerce. Bulletin of the Transilvania University of Brasov, 9(58), 301-308. Retrieved April 20, 2017, from http://webbut.unitbv.ro/Bulletin/Series\%20V/2016/ BULETIN\%20I\%20PDF/34_Neacsu.pdf.

Petrović-Tomić, N. (2014). Rešavanje potrošačkih sporova pred arbitražom. Anali Pravnog fakulteta u Beogradu, 62(2), 86-114. DOI:10.5937/AnaliPFB1402086T In Serbian.

Perinčić, D. (2014). Ostvarivanje prava potrošača. Beograd: Zadužbina Andrejević. In Serbian.

Prlja, D., Reljanović, M., \& Ivanović, Z. (2012). Internet pravo. Beograd: Institut za uporedno pravo. In Serbian. 
Petrić, S. (2015). Temeljna obilježja prava zaštite potrošača Republike Hrvatske u svjetlu novog Zakona o zaštiti potrošača. Zbornik radova Pravnog fakulteta u Nišu, 70, 719-736. In Serbian.

Schu, R. (1996). Consumer protection in private international law in Internet contracts. Arelano Law and Policy Review, 8(2), 31-98. Retrieved April 21, 2017, from http://www.arellanolaw.edu/alpr/v8n2c.pdf.

Sikirić, H. (2006). Mjerodavno pravo za ugovore u elektroničkoj trgovini u hrvatskom i međunarodnom privatnom pravu. Zbornik Pravnog fakulteta u Zagrebu, 56, 739-789. In Croatian.

Simović, K. (2014). Slobodno kretanje robe u kontekstu pregovora o pristupanju Evropskoj uniji: praktična pitanja, prilike, i izazovi efikasne integracije Republike Srbije u Jedinstveno tržište. Beograd: Centar za evropske politike. In Serbian.

Stanisavljev, S., Đorđević, D., \& Coćkalo, D. (2012). Analysis of competitiveness of domestic enterprises on the global market. Singidunum Journal of Applied Sciences, 9(1), 1-8. Retrieved April 15, 2017, from http://journal. singidunum.ac.rs/files/2012-9-1/analysis-of-competitiveness-of-domestic-enterprises-on-the-global-market. pdf.

Stanivuković, M. (2001). Instrumenti unifikacije i harmonizacije prava i njihov odnos prema kolizionim normama s posebnim osvrtom na Načela evropskog ugovornog prava. Zbornik referata sa savetovanja održanog na Pravnom fakultetu u Kragujevcu, November 15-16, 2001 (pp. 57-93). Kragujevac: Pravni fakultet u Kragujevcu. In Serbian.

Stojanović, I. (2011). Elektronska trgovina i kupovina putem Interneta u Srbiji. Beograd: Univerzitet Singidunum. Retrieved March 15, 2017 from https://singipedia.singidunum.ac.rs/izdanje/41837-elektronska-trgovina-ikupovina-putem-interneta-u-srbiji. In Serbian.

The European Consumer Centres Network. (2015). Anniversary Report 2005-2015. Retrieved March 16, 2017, from http://ec.europa.eu/consumers/solving_consumer_disputes/non-judicial_redress/ecc-net/docs/ecc_net_-_anniversary_report_2015_en.pdf doi: 102772/47086.

Vasiljević, M. (2009). Poslovno pravo Srbije i Evropska unija. Pravo i privreda, 46(1-4), 11-46. In Serbian.

Vukadinović, R. (1999). Pojam i značaj usklađivanja (harmonizacije) domaćeg prava sa pravom Evropske unije. Sa naučno-stručnog skupa, 24-25 December 1998 (pp. 35-50). Niš: Pravni fakultet u Nišu. In Serbian.

Vukadinović, R. (2009). Upotreba i zloupotreba harmonizacije domaćeg prava sa pravom Evropske unije. Zbornik radova Pravo Republike Srbije i pravo Evropske unije - stanje i perspektive, 1(1), 1-19. In Serbian.

\section{ZAŠTITA POTROŠAČA U INTERNET PRODAJI - STEPEN HARMONIZACIJE SA PRAVOM EVROPSKE UNIJE}

\section{Rezime:}

U ovom radu autori će nastojati da daju odgovor na neka opšta pitanja koja se tiču pojma, značaja i ciljeva harmonizacije ugovornog prava. S obzirom na aktuelnost i masovnost internet prodaje, pitanje zaštite potrošača autori će postaviti u granicama ove uske oblasti ugovornog prava. U centralnom delu rada autori će prikazati najznačajnije propise kojima se reguliše ova oblast u Evropskoj uniji i Srbiji, kao i stepen njihove harmonizacije. Takođe, nastojaće da daju odgovore na neka osnovna pitanja i probleme sa kojima se potrošači susreću prilikom internet kupovine. U Srbiji je donet niz zakona koji prate zahteve i standarde Evropske unije. Međutim, neophodno je stalno sprovoditi i proces edukacije zaposlenih $\mathrm{u}$ državnim službama, trgovaca, ali i samih potrošača, radi širenja svesti o značaju i koristima elektronske trgovine, pre svega zbog zaštite potrošača.

\section{Ključne reči:}

internet prodaja, Evropska unija, ugovor, zaštita potrošača. 